\title{
The influence of problem based learning towards social science learning outcomes viewed from learning interest
}

\author{
Berti Dyah Permatasari ${ }^{1}$, Gunarhadi $^{2}$, Riyadi $^{3}$ \\ ${ }^{1,3}$ Department of Elementary School Teacher Training and Education, Sebelas Maret University, Indonesia \\ ${ }^{2}$ Department of Educational Science, Sebelas Maret University, Indonesia
}

\begin{tabular}{l}
\hline Article Info \\
\hline Article history: \\
Received Sep 17, 2018 \\
Revised Oct 29, 2018 \\
Accepted Nov 15, 2018 \\
\hline
\end{tabular}

Keywords:

Learning interest

Learning outcomes

Problem based learning

Social science

\begin{abstract}
The aim of this study is to determine the influences of Problem Based Learning and learning interest at improving the cognitive learning outcomes in social science of fourth-grade elementary school students. This study is a quasi-experiment study with pre-test and post-test control group design. The sample collection is taken with stratified cluster random sampling technique. The sample of this study is 109 fourth-grade elementary school students, consisted of 50 students from experiment group and 59 students from control group. The students from experiment group are given the application of Problem Based Learning, while the students in control group are given the application of Direct Instruction. The data collection is carried by using the instruments of social science learning outcomes test and social science learning interest questionnaire. The validity of test and questionnaire instruments is carried by expert judgement. The difficulty level, distinguishing power, and reliability of test instrument are tested by using ITEMAN application. The internal consistency and reliability of questionnaire instrument is tested by using SPSS application. The data is analysed by using two-way anova. The outcomes of the study show that PBL and learning interest contribute significant impact towards social science learning outcomes of elementary school students.
\end{abstract}

Copyright $(\mathbb{C} 2019$ Institute of Advanced Engineering and Science. All rights reserved.

\section{Corresponding Author:}

Berti Dyah Permatasari,

Department of Elementary School Teacher Training and Education,

Sebelas Maret University,

J1. Ir. Sutami No.36A, Jebres, Surakarta, Jawa Tengah, Indonesia (57126).

Email: bertidyahp@student.uns.ac.id

\section{INTRODUCTION}

One of the roles of national education in Indonesia is to prepare perceptive students on facing hard challenge in global society life that constantly changes. This goes in line with Act of The Republic of Indonesia Number 20, Year 2003 on National Education System, Article 1 Section 2 which translates "National education means education based on Pancasila and the 1945 Constitution, and is rooted in the religious values, national cultures of Indonesia, and one that is responsive to the needs of the ever-changing era." [1]. One of the subjects in elementary school which is designed to prepare students to face the changing age is social science, as stated by Nurcahyo and Hartono that social science education in elementary school is aimed for students to develop knowledge and basic skills which benefit themselves in their daily life [2]. Social science itself is defined as educational program that chooses educational material from social and humanities science which are scientifically and psychologically organized and served for educational purpose [3]. This definition shows that social science's one of its main characteristics is cooperation among educational science and social sciences. In Ministrial Regulation Number 22, Year 2006 on Content Standard, it is mentioned that "Social Science subject is designed to develop the knowledge, comprehension, and analysis ability on society social condition in entering dynamic civilization life." [4]. The objective of 
social science is then formulated into four categories: (1) Knowledge, that helps students study themselves and their environment, includes geography, history, politics, economy, anthropology and socio-psychology; (2) Skill, which in this case includes thinking skills; (3) Attitudes, grouped into two: intellectual behaviour and social behaviour; (4) Value, which in this case is value contained in society obtained from local society or government organisation (nation philosophy) [2]. Hence, social science education in elementary school emphasize more on how to educate students to recognise, comprehend, and to be able to apply knowledge, skills, values, and moral into living among society and nation.

Referring to the said objectives, social science has a very important role for students' lives, both now and in the future. But unfortunately, the process of learning social studies in elementary schools still lacks the attention of both teachers and students. The problem in social studies learning that is often encountered is the weakness of the learning process. Learning is still teacher-centered, teachers are less encouraged to develop the ability to think, learning is only directed at the child's ability to memorise information [5]. Teachercentered learning also means that teachers tend to be dominant (actively involved) in carrying the lesson content to the students and teach them directly to students in the classroom through lectures, discussion and assignments. Conventional learning is called direct learning/direct instruction [6]. Conventional learning which is also dominated by the view that knowledge is a fact that must be memorised can result in students becoming passive in learning, ways of thinking are less developed because they only focus on the theory but are not stimulated to think critically on problems that occur in everyday life. This is what makes social science learning seem monotonous, boring, and memorised, therefore students have less interest in learning social studies.

The learning paradigm should be changed from teacher-centered to student-centered so that the problem of social science learning can be overcome. Therefore, students are not only used as learning objects, but as subjects of learning. Students are really guided and facilitated to build their own knowledge, not merely moving the contents of the teacher's head to the student's head. Learning should not only be focused on providing theoretical knowledge, but students are also given learning experiences that are always related to the actual problems that occur in their environment [7]. Thus, the selection and application of learning approaches and models greatly influence the achievement of learning goals. The student-centered education process, which aims to develop key skills, needs to involve a proactive approach that facilitates student involvement in research, scientific inquiry, analysis of problematic situations or solving real problems or just hypothetical problems. Through its specificity, Problem Based Learning (PBL) can be a major component in such teaching approaches [8].

Problem Based Learning (PBL) is often referred to as Inquiry Based Learning. Cognitiveconstructivist views, which underlie problem-based learning (PBL), mostly follow Piaget. This view states that students at any age are actively involved in the process of obtaining information and building their own knowledge. While Vygotsky believe that intelligence develops because individuals face confusing new experiences, so they try to resolve gaps that arise from this experience [9].

Along with the changing of the times, many experts provided definitions about the PBL model. Problem Based Learning (PBL) is a learning model that is oriented to the active role of students by exposing students to a problem with the aim of students being able to actively solve existing problems and then draw conclusions by determining what steps they should be done [10]. The problem presented is a problem related to the real world. The closer to the real world, the better the effect will be on improving learner skills [11]. Based on the problem given, students work together in groups to solve these problems by referring to the knowledge they already have and from relevant new information. With this PBL model, students are directly involved in learning activities so that their knowledge can be absorbed properly. In addition, this learning model allows students to interact and collaborate with group friends so that it is expected to encourage students' interest in learning.

Various studies in the world of education recognize the success of their learning by applying Problem Based Learning. Students who study with PBL score high after learning and their scientific process skills also increase [12]. In addition to scores, high school students majoring in social studies subject to PBL models also demonstrate the ability to solve geographic problems that are higher than the classes subject to conventional models [13]. At the end of the PBL process, students can identify and solve problems with their own ideas and abilities and develop their creative thinking, which is one of the higher-order thinking skills [14].

The right learning model is only one of the factors that can influence the success of the learning process. Learning models fall into the category of external factors, while there is still one more factor, namely the internal factor, which covers three more factors. These three factors are physical factors, psychological factors, and fatigue factors. Physical factors, including health and disability factors; Psychological factors, including intelligence, attention, interests, talents, motives, maturity, and readiness; Fatigue factors, including physical fatigue and spiritual fatigue [15]. From some of these internal factors,

Int. J. Eval. \& Res. Educ. Vol. 8, No. 1, March 2019: 39 - 46 
there is an interesting one to study, namely the interest factor. Interest in learning is an individual's tendency to have pleasure without coercion so that it can cause changes in knowledge, skills and behaviour. Interest can affect the quality of achievement of student learning outcomes in certain fields of study because he will focus more on the field than other students [16]. Therefore, teachers must recognize how much learning interest students have and grow them so that the learning process can run effectively and achieved success in learning.

Success in learning can be measured from three domains; they are cognitive, affective, and psychomotor. The cognitive domain includes intellectual abilities associated with mental processes or activities from low to high categories; affective domains are related to feelings, emotions, attitudes, degrees of acceptance or rejection of an object; and the psychomotor domain is related to the competence to do work that involves members, and competencies related to physical movement [17]. Learning outcomes measured in three domains by Bloom were later revised by Anderson \& Krathwohl. The cognitive domain consists of remembering, understanding, applying, analysing, evaluating, and creating; affective domain consists of receiving, responding, evaluating, organizing, and forming characterization; psychomotor domains consist of perception, manipulating, performing procedures (precision), doing well and correctly (articulation), and acting naturally (naturalisation) [18].

The learning outcomes here as the dependent variable are the effects of the application of the learning model and student interest in social science. The intended learning outcomes are cognitive domains which consist of C1-C6 (remembering to create). Remembering is related to students' ability to recognise and recall; understanding is related to the ability to interpret, exemplify, classify, summarise, conclude, compare, and explain; applying is about the ability to implement, execute / implement; analyse related to the ability to distinguish, organise, and associate; assess related to the ability to examine and criticize; and creating is related to the ability to produce, plan, and produce [19].

Researches that have been conducted solely are to improve the quality of learning in ways that can attract students' interests and stimulate students to think critically. Previous studies, especially for PBL models have shown the effectiveness of this model in improving the ability and learning outcomes of high school Geography subjects [13]; Science [14], [8], [20]; and Chemistry [12], [21]. From the various studies above, learning with PBL models, in addition to improving learning outcomes can also improve other abilities and skills in students such as problem-solving skills, scientific process skills, critical thinking skills and creative. Among these studies, PBL is widely used for science learning, while for social science is viewed from the interest of students in elementary school learning is still rare. Therefore, it is necessary to conduct research to examine the effectiveness of PBL in social studies learning in elementary schools based on students' learning interests.

The aim of this study is to determine differences in the effect of Problem Based Learning (PBL) model and Direct Instruction (DI) on the results of social sciences. This study also examines the differences in social science learning outcomes obtained by groups of students who had different levels of learning interest; and the interaction between the learning model and the learning interest of students towards social science learning outcomes.

\section{RESEARCH METHOD}

This study is a quasi-experimental study with pre-test and post-test control group design. The variables of this study consisted of learning models as independent variables, which are Problem Based Learning (PBL) and Direct Instruction (DI) models; learning interest as moderator variables with the dimensions of high learning interest (HLI), moderate learning interest (MLI), and low learning interest (LLI); and social science learning outcomes as dependent variable. In addition, there are confounding variables that are not included in the study, but can affect the dependent variable. Confounding variables in this study are learning time and health. Confounding variables "Learning Time" can be minimized by carrying out learning in all classes in the morning. Meanwhile, "Health" cannot be controlled; therefore the effect is considered the same or ignored.

This research was conducted at the Polokarto District Elementary School, Sukoharjo Regency. The population of this study was all fourth-grade students of public elementary schools in Polokarto District, Sukoharjo Regency consisting of 43 schools. The sample in this study took 6 classes from 6 elementary schools totalling 109 students, with 50 students from the experimental group treated using Problem Based Learning model and 59 students from the control group were treated using Direct Instruction models. The research sample was taken by stratified cluster random sampling technique. Stratified cluster random sampling is a combination of stratified random sampling methods with cluster random samples, because the population or target population is quite large and wide, is rarely random or has the same characteristics [22].

The influence of problem based learning towards social science learning... (Berti Dyah Permatasari) 
Data collection uses test and questionnaire instruments. Multiple choice test instruments with a total of 25 questions were used to find out the results of students' social studies learning. Questionnaire instruments in the form of 15 statements represent the magnitude of students' interest in social science. Questionnaire with Likert scale (1-5) to classify students' learning interest into three levels, which are high, medium, and low. Before being used for data collection, each instrument has been tested first. Furthermore, the test instruments were tested for content validity, level of difficulty, distinguishing power, and reliability, while the questionnaire instruments were tested for content validity, internal consistency, and reliability. Test the validity of the test results of learning outcomes and questionnaires of interest in learning is done through expert judgment, both in terms of material, construction, and language. Test of the level of difficulty, distinguishing power and reliability of the test instrument was carried out with the ITEMAN application, while the internal consistency test and the reliability of the interest learning questionnaire instruments were conducted with the help of the SPSS application. Based on the results of a series of tests of validity and reliability, the test instruments for social studies learning outcomes and questionnaires of interest in social studies have met the criteria for reviewing items that are good and suitable for research.

At the data analysis stage, before being given a different treatment, tests were carried out for the prerequisite tests of variance analysis and balance tests in the experimental group and the control group. Prerequisite test includes population normality test using Lilliefors method and population variance homogeneity test using the Bartlett method, while the balance test uses one-way Anova. The result is that both groups come from populations that are normally distributed and homogeneous; and have a balanced initial ability. After the sample was given a different treatment, the collected or analysed was then analysed using two-way Anova with unequal cells.

\section{RESULTS AND DISCUSSION}

Before being given treatment, both groups were tested through pre-test. After being treated by applying PBL model for the experimental group and DI for the control group, the ability of students was tested again by giving a post-test to find out the learning outcomes in social studies learning. Both the pretest and post-test data were tested for normality using the Liliefors method and tested for homogeneity using the Bartlett test. From the results of the pre-test, the mean was obtained $\bar{X}=47.84$ in the experimental group and $\bar{X}=43.93$ in the control group. Then from the results of the post-test, the mean was obtained $\bar{X}=74.24$ in the experimental group and $\bar{X}=51.80$ in the control group class.

Data that has been known to be normal and homogeneous, then tested the hypothesis with two way Anova different cell paths. The results of hypothesis testing with two-way Anova can be seen in Table 1 . Through hypothesis testing, obtained $\mathrm{F}_{\mathrm{a}}=54.929>3.933 ; \mathrm{F}_{\mathrm{b}}=5.409>3.085 ; \mathrm{F}_{\mathrm{ab}}=0.330<3.085$ so that the decision of the $\mathrm{H}_{0 \mathrm{~A}}$ test is rejected, $\mathrm{H}_{0 \mathrm{~B}}$ is rejected, and $\mathrm{H}_{0 \mathrm{AB}}$ is accepted. $\mathrm{H}_{0 \mathrm{~A}}$ rejected means that there is an influence between PBL and DI learning models on social science learning outcomes; $\mathrm{H}_{0 \mathrm{~B}}$ is rejected meaning that there are differences in the influence of learning interest on social science learning outcomes; and $\mathrm{H}_{0 \mathrm{AB}}$ is accepted, meaning that there is no interaction between learning models and learning interest in social science learning outcomes.

Table 1. Anova test results on social science learning outcomes

\begin{tabular}{cccl}
\hline Source & $\mathrm{F}_{\text {count }}$ & $\mathrm{F}_{\text {table }}$ & Test Decision \\
\hline Learning Model (A) & 54.929 & 3.933 & $\mathrm{H}_{0 \mathrm{~A}}$ is rejected \\
Learning Interest (B) & 5.409 & 3.085 & $\mathrm{H}_{0 \mathrm{~B}}$ is rejected \\
Interaction (AB) & 0.330 & 3.085 & $\mathrm{H}_{0 \mathrm{AB}}$ is accepted \\
\hline
\end{tabular}

\subsection{Effect of learning models on social science learning outcomes}

Anava test results show $\mathrm{F}_{\mathrm{a}}=54.929>3.933$, it can be said that there is an effect of the application of learning models on learning outcomes. The results of pre-test and post-test in the experimental group and the control group can be seen in detail in Table 2. Based on the results of post-test on social studies subjects, the average student taught using the PBL model was higher and higher than the average student who was taught using DI (Direct Instruction) model, although both experienced an increase from the results of the pretest. Therefore, it can be concluded that the results of social science of students who were treated with PBL model were better than students who were treated with the DI model.

A significant increase in social science learning outcomes of students taught using PBL model shows the effectiveness of the model in helping students learn social science. The existence of problems underlying the learning process has stimulated students to think critically and analytically to solve these

Int. J. Eval. \& Res. Educ. Vol. 8, No. 1, March 2019: 39 - 46 
problems through PBL steps and learning in small groups can foster interaction between students so that learning feels good and students' learning interest can increase.

Table 2. Differences of pre-test and post-test results of experimental class and class controls

\begin{tabular}{ccccccccc}
\hline \multirow{2}{*}{ Test } & & \multicolumn{6}{c}{ Result } \\
& Class & $\mathrm{n}$ & $\overline{\mathrm{X}}$ & Mo & Me & Max & Min & Standard \\
\hline \multirow{2}{*}{ Pre-test } & Experiment & 50 & 47.84 & 56.00 & 48.00 & 76.00 & 12.00 & 13.33 \\
& Control & 59 & 43.93 & 44.00 & 44.00 & 72.00 & 12.00 & 13.26 \\
\multirow{2}{*}{ Post-test } & Experiment & 50 & 74.16 & 68.00 & 72.00 & 100 & 24.00 & 16.80 \\
& Control & 59 & 51.80 & 60.00 & 52.00 & 80.00 & 24.00 & 12.77 \\
\hline
\end{tabular}

The first finding shows that PBL model is more effective than DI model. This finding is parallel with the results of previous studies that the learning outcomes of students studying with PBL models significantly increased based on pre-test and post-test and the scientific process skills of students also increased [12]. Similar research shows that there are statistically significant differences in the mean post-test achievement scores on Teacher-Made Test (TMT) and the average post-test achievement scores at Researcher-Designed Test (RDT) between students who study with Problem Based Learning (PBL) and those who study with traditional methods or Traditional Method (TM) [23]. Another study is also shown that the PBL method is more effective than TTM in students' conceptual development [24].

Besides being able to significantly improve learning outcomes, PBL model is also believed to improve problem solving skills and develop critical and creative thinking. This is reinforced by the findings that classes that are subject to PBL models have a higher problem-solving ability than classes subjected to conventional models [13]. Another research shows the same thing, namely at the end of PBL process, students can identify and solve problems with their own ideas and abilities and develop their creative thinking [14]. PBL model is indeed effective to improve learning outcomes and the ability to think and solve problems, but it requires careful planning and good communication between teachers and students. This is because the quality of communication between teachers and students is very important, teachers are considered as partners, as active participants, during training activities [20]. Furthermore, teachers must pay more attention to feedback received from students, to control and adjust well to the training process.

\subsection{The effect of learning interest on learning outcomes}

Anava test results showed $\mathrm{F}_{\mathrm{b}}=5.409>3.085$ so the test decision was rejected by $\mathrm{H}_{0 \mathrm{~B}}$. This means that there is an influence of students' learning interest on social studies learning outcomes. This finding is in line with the findings of Nurhasanah \& Sobandi which shows that interest in learning has a significant influence on learning outcomes. Student learning outcomes can be improved through increasing student learning interest, which means that the better the student's learning interest will have an impact on student learning outcomes that are getting better [25]. Other findings also show similar results that interest in learning has a positive effect on learning outcomes in English subjects [26], Arabic[27], Economics [28], [29].

The decision of the $\mathrm{H}_{0 \mathrm{~B}}$ test was rejected also meant that the social science learning outcomes of students could be different in each category of high, medium and low learning interest. Therefore, further testing is needed after Anava to find out what students with learning interest have better learning outcomes. The results of the calculation of the average comparative test between columns are presented in Table 3.

Table 3. Summary of inter column average comparison test results

\begin{tabular}{cccccc}
\hline No. & Interaction & $\mathrm{F}_{\mathrm{obs}}$ & $\mathrm{F}_{\text {table }}$ & Decision & Marginal mean \\
\hline 1 & $\mu_{.1} v s \mu_{.2}$ & 9.801 & 6.169 & $\mathrm{H}_{0}$ is rejected & $\bar{X}_{1}>\bar{X}_{2}$ \\
2 & $\mu_{1} v s \mu_{2}$ & 10.259 & 6.169 & $\mathrm{H}_{0}$ is rejected & $\bar{X}_{1}>\bar{X}_{2}$ \\
3 & $\mu_{.2} v s \mu_{3}$ & 0.734 & 6.169 & $\mathrm{H}_{0}$ is accepted & $\bar{X}_{.2}>\bar{X}_{.3}$ \\
\hline
\end{tabular}

From Table 3 it can be seen that there $\mathrm{H}_{0}$ is rejected, and is based on the average marginal as presented in Table 3. It can be concluded that the results of social science students with an interest in learning the high better than the results of social science students with an interest in learning medium. The results of social science students with high interest in learning better than the results of social science students with low learning interest, while the results of social science of students with learning interest are as good as social science learning outcomes of students with low learning interest.

The influence of problem based learning towards social science learning... (Berti Dyah Permatasari) 


\subsection{Interaction between learning models and learning interest}

Based on the Anava test, obtained $\mathrm{F}_{\mathrm{ab}}=0.330<3.085$ so that the $\mathrm{H}_{0 \mathrm{AB}}$ test decision is accepted. $\mathrm{H}_{0 \mathrm{AB}}$ is accepted which means that there is no interaction between learning models and learning interest in social science learning outcomes. Therefore, the comparison between the use of PBL and DI models for each level of learning interest follows the ratio of the marginal mean. Graphically, the absence of interaction between learning models and interest in learning can be seen in Figure 1. In the figure, the profiles of PBL and DI models do not intersect. From that profile, it can also be seen that the average for students who are subjected to PBL model is always higher than the average for students who are subjected to DI model, both for students with high, medium, and low learning interest. This means that the social science learning outcomes of students who study with PBL models are always better than the social science learning outcomes of students who study with DI model at any level of learning.

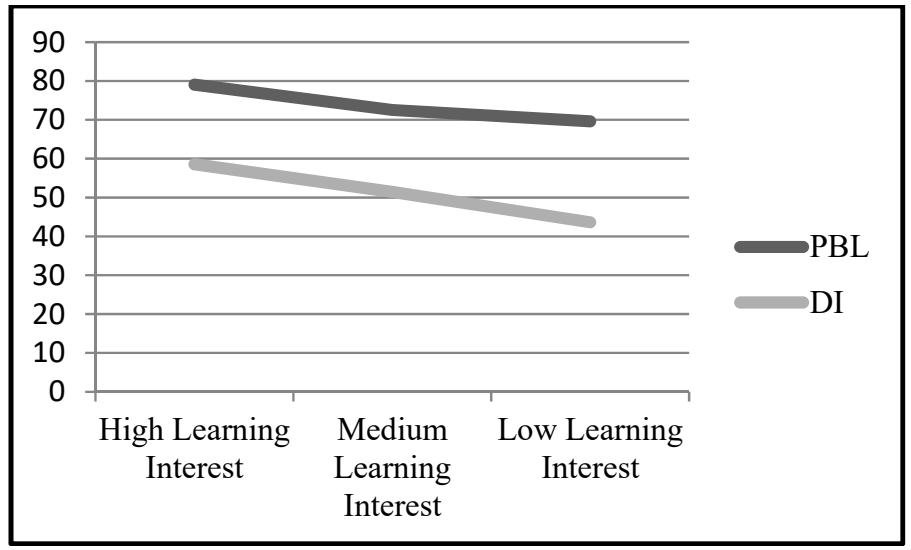

Figure 1. Effect profile of learning model variables

\section{CONCLUSION}

Problem Based Learning (PBL) model has much higher effectiveness than conventional learning models namely Direct Instruction (DI) in improving social science learning outcomes. This PBL model can be used as an alternative in learning that is more innovative, fun, and challenging for students in social science because students can build their own knowledge by solving problems that are similar with the real world. In addition to the learning model used, the level of interest in learning also influences the success of students in learning social science, although in this study there was no interaction between learning models and interest in learning. Students with high learning interest are more eager to learn and get better results than students with moderate and low learning interests. Furthermore, Problem Based Learning model can be developed according to the needs of students or developed in the form of teaching materials to facilitate teachers in teaching this model.

\section{REFERENCES}

[1] Ministry of Education. Act of The Republic of Indonesia Number 20, Year 2003 on National Education System, Article 1 Section 2. Jakarta: Ministry of Education, 2003.

[2] A. Nurcahyo and Y.Hartono. Basic Concept and Development of Social Science-Elementary School. Magetan: Lembaga Edukasi Swastika Press, pp. 6-7, 73, 2011.

[3] M. N. Soemantri. Social Sciences Education Viewed from the Perspective of Actualization. Jakarta: IKIP Jakarta, pp.3, 2001.

[4] Ministrial Regulation Number 22, Year 2006 on Content Standard. Jakarta: Directorate General of Primary and Secondary Education Management.

[5] Sutomo, "Effect of Jigsaw Cooperative Learning Strategy and Social Skills on Social Science Learning Outcomes," Jurnal Ilmu Pendidikan, vol. 23, issue. 1, pp. 11-18, 2017.

[6] A. Suprijono, Agus. Cooperative Learning: PAIKEM Theory and Application. Yogyakarta: Pustaka Pelajar, 2013, pp. 47.

[7] Rusman. Learning Models. Jakarta: PT Raja Grafindo Persada, pp. 187, 2013.

Int. J. Eval. \& Res. Educ. Vol. 8, No. 1, March 2019: 39 - 46 
[8] Drăghicescu et al, Application of Problem-Based Learning Strategy in Science lessons - Examples of Good Practice," Procedia - Social and Behavioral Sciences, vol. 149, pp. 297 - 301, 2014.

[9] R. I. Arends. Learning to Teach. Jakarta: Salemba Hamanika, pp. 104-105, 2013.

[10] S. M. Wardoyo. Research Based Learning. Jakarta: Akademia Permata, pp. 40, 2013.

[11] M. T. Amir. Educational Innovation through Problem Based Learning: How Educators Empower Students in the Knowledge Age. Jakarta: Prenada Media Group, pp. 22, 2009.

[12] A. Gurses, C. Dogar, \& E. Geyik, "Teaching Of The Concept Of Enthalpy Using Problem Based Learning Approach," Procedia - Social and Behavioral Sciences, vol. 197, pp. 2390 - 2394, 2015.

[13] Sujiono, Handoyo, \& Ruja, "Solving Geographic Problems through Problem Based Learning," Jurnal Teori dan Praksis Pembelajaran IPS, vol. 2, issue. 2, pp. 14-20, 2017.

[14] E. Ersoy and N. Baser, "The Effects of Problem-Based Learning Method in Higher Education," Procedia - Social and Behavioral Sciences, vol. 116, pp. 3494 - 3498, 2014.

[15] Slameto. Learning and Affecting Factors. Jakarta: PT Rineka Cipta, pp. 54-72, 2013.

[16] M. Syah. Educational Psychology. Bandung: PT Remaja Rosdakarya, pp. 134, 2010.

[17] B. S. Bloom, B.S. Taxonomy of Education objective. Handbook.I: Cognitive domain. New York: McKay. 1981.

[18] L.W. Anderson and D. R. Krathwohl. A Taxonomy of Learning, Teaching and Assessing, a Revision of Bloom Taxonomy of Educational Objective. New York: Longman, 2001.

[19] L. W. Anderson. Classroom Assessment: Enhancing the Quality of Teacher Decision Making. London: Lawrence Erlbaum Associates, 2003.

[20] G. Gorghiu, et al, "Problem-Based Learning - An Efficient Learning Strategy in The Science Lessons Context," Procedia - Social and Behavioral Sciences, vol. 191, pp. 1865 - 1870, 2015.

[21] S. Temel, "The Effects of Problem-Based Learning on Pre-Service Teachers' Critical Thinking Dispositions and Perceptions of Problem-Solving Ability," South African Journal of Education, vol. 34, issue. 1, pp. 1-20, 2014.

[22] N. S. Sukmadinata. Educational Research Methods. Bandung: PT Remaja Rosdakarya, pp. 259, 2013.

[23] A. O. Fatade, D. Mogari, \& A.A. Arigbabu, "Effect of Problem-Based Learning on Senior Secondary School Students' Achievements In Further Mathematics," Acta Didactica Napocensia, vol. 6, issue. 3, pp 27-43, 2013.

[24] A. K. Tasoglu and M. Bakac, "The Effects of Problem Based Learning and Traditional Teaching Methods on Students' Academic Achievement, Conceptual Developments and Scientific Process Skills According to Their Graduated High School Types," Procedia Social and Behavioral Science, vol. 2, pp. 2409-2413, 2010.

[25] S. Nurhasanah \& Sobandi, "Learning Interest as Determinant Student Learning Outcomes," Jurnal Pendidikan Manajemen Perkantoran, vol. 1, issue. 1. pp. 135-142, 2016.

[26] P. Zhang, Z. Wang, and O. Adesope, "The Effects of Goal Type, Learning Interest, and Task Difficulty on Learning English Words," International Journal of Learning, Teaching and Educational Research, vol. 15, issue. 2, pp. 3246, 2016.

[27] M. A. Kurniawan, "Contributions of Teacher Professionalism and Interest in Learning towards Arabic Learning Outcomes,". Jurnal Penelitian dan Penilaian Pendidikan, 2(2), 257-273, 2017.

[28] I. R. Nuraini, "The Effect of Father's Income and Learning Interest on Economic Learning Outcomes of Students in X Grade SMA Negeri 1 PAKEM 2015/2016 Academic Year," Jurnal Pendidikan dan Ekonomi, vol. 6, issue. 1. pp. 28-37, 2017.

[29] Z. A. Sukarno \& P. Hardinto, "The Influence of the Use of Gadgets, Learning Interests and Emotional Intelligence on the Learning Outcomes of XI Grade IIS Students in Economic Subjects at SMAN 1 Kepanjen," Jurnal Pendidikan Ekonomi, vol. 11, issue, 1. pp. 9-19, 2018. 


\section{BIOGRAPHIES OF AUTHORS}

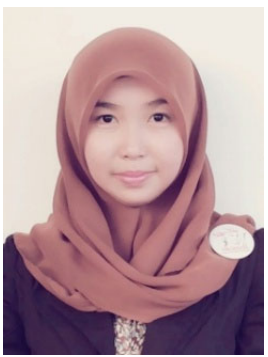

Berti Dyah Permatasari graduated from Elementary School teacher Training and Education at Sebelas Maret University in 2015. She has been doing her master's degree at the same department at Sebelas Maret University. Her research interest is implementation of learning model for elementary school students.

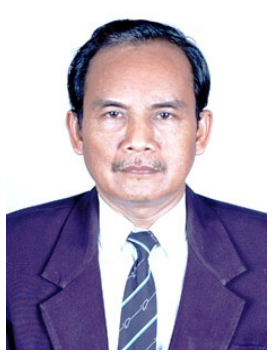

Prof. Drs. Gunarhadi completed his MA degree at Institute of Special Education, Norway, Special Education for The Phyically Handicapped Children Program and his Ph.D degree at Universiti Utara Malaysia, Special Education Program. He has been working at Sebelas Maret University, Department of Educational Science. His research interests are inclusive education policy and its implementation, inclusive education strategy, treatments for children with special needs, treatments for street children, and development of sustainable training model for special supervising teacher.

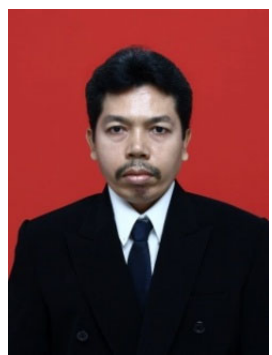

Dr. Riyadi completed his Master of Science and Doctoral Degree in Mathematics Science at Gadjah Mada University. He works in Department of Elementary School Teacher Training and Education, Sebelas Maret University. His research interests are curriculum development, learning model and media, PJJ Program implementation evaluation, and learning creativity and motivation improvement

Int. J. Eval. \& Res. Educ. Vol. 8, No. 1, March 2019: 39 - 46 